\title{
Variability in Populus leaf anatomy and morphology in relation to canopy position, biomass production, and varietal taxon
}

\author{
Najwa AL AFAS ${ }^{\mathrm{a}}$, Nicolas MARRON ${ }^{\mathrm{a}, \mathrm{b}}$, Reinhart CEULEMANS ${ }^{\mathrm{a} *}$ \\ ${ }^{\text {a }}$ University of Antwerp, Department of Biology, Universiteitsplein 1, 2610 Wilrijk, Belgium \\ ${ }^{\mathrm{b}}$ Present address: UMR 1137 INRA-UHP Écologie et écophysiologie forestières, 54280 Champenoux, France
}

(Received 14 November 2006; accepted 29 January 2007)

\begin{abstract}
Twelve poplar (Populus) genotypes, belonging to different taxa and to the sections Aigeiros and Tacamahaca, were studied during the third growing season of the second rotation of a high density coppice culture. With the objective to highlight the relationships between leaf traits, biomass production and taxon as well as the influence of canopy position, anatomical and morphological leaf characteristics (i.e. thickness of epidermis, of palisade and spongy parenchyma layers, density and length of stomata, leaf area, specific leaf area (SLA) and nitrogen concentration) were examined for mature leaves from all genotypes and at two canopy positions (upper and lower canopy). Above ground biomass production, anatomical traits, stomatal and morphological leaf characteristics varied significantly among genotypes and between canopy positions. The spongy parenchyma layer was thicker than the palisade parenchyma layer for all genotypes and irrespective of canopy position, except for genotypes belonging to the $P$. deltoides $\times$ P. nigra taxon (section Aigeiros). Leaves at the upper canopy position had higher stomatal density and thicker anatomical layers than leaves at the lower canopy position. Leaf area and nitrogen concentration increased from the bottom to the top of the canopy, while SLA decreased. Positive correlations between biomass production and abaxial stomatal density, as well as between biomass production and nitrogen concentration were found. A principal component analysis (PCA) showed that genotypes belonging to the same taxon had similar anatomical characteristics, and genotypes of the same section also showed common leaf characteristics. However, Wolterson (P. nigra) differed in anatomical leaf characteristics from other genotypes belonging to the same section (section Aigeiros). Hybrids between the two sections (Aigeiros $\times$ Tacamahaca) expressed leaf characteristics intermediate between both sections, while their biomass production was low.
\end{abstract}

Populus spp. / taxon / stomatal density and length / thickness of leaf anatomical layers / nitrogen concentration / specific leaf area / productivity

Résumé - Variabilité des caractères foliaires anatomiques et morphologiques du peuplier en relation avec la position des feuilles dans la canopée, la production de biomasse et le taxon. Douze génotypes de peuplier (Populus), appartenant à différents taxa ainsi qu'aux sections Aigeiros et Tacamahaca, ont été étudiés durant la troisième saison de croissance de la deuxième rotation d'une plantation à forte densité. L'objectif de l'expérience était de mettre en évidence les relations entre les caractères foliaires, la production de biomasse et le taxon, ainsi que l'influence de la position des feuilles dans la canopée. Pour ce faire, diverses caractéristiques anatomiques et morphologiques des feuilles (épaisseur des épidermes et des parenchymes palissadique et lacuneux, densité et longueur des stomates, surface foliaire, surface foliaire spécifique (SLA) et teneurs en azote) ont été déterminées pour des feuilles matures de tous les génotypes et à deux hauteurs dans la canopée (haute et basse). La production de biomasse aérienne et les caractères foliaires anatomiques et morphologiques variaient significativement entre génotypes et entre positions dans la canopée. Le parenchyme lacuneux était plus épais que le parenchyme palissadique pour tous les génotypes et quel que soit la hauteur dans la canopée, excepté pour les génotypes appartenant au taxon $P$. deltoides $\times$ P. nigra (section Aigeiros). Les feuilles du sommet de la canopée présentaient des densités de stomates et des épaisseurs de tissus plus importantes que les feuilles de la base de la canopée. La surface des feuilles et leurs teneurs en azote augmentaient de la base vers le sommet de la canopée, tandis que les SLA diminuaient. Des corrélations positives entre la production aérienne de biomasse et la densité de stomates abaxiale ainsi qu'entre la production de biomasse et la teneur en azote foliaire ont été mises en évidence. Une analyse en composantes principales (ACP) a montré que les génotypes appartenant au même taxon présentaient des caractéristiques anatomiques similaires, et que les génotypes de la même section montraient également des caractéristiques foliaires communes. Wolterson ( $P$. nigra) était cependant différent des autres génotypes de la même section (section Aigeiros) en termes de caractères anatomiques. Les hybrides entre les deux sections (Aigeiros $\times$ Tacamahaca) présentaient des caractéristiques foliaires intermédiaires entre les sections, alors que leur production de biomasse était faible.

Populus spp. / taxon / densité et longueur des stomates / épaisseur des tissus anatomiques foliaires / teneur en azote / surface foliaire spécifique / productivité

\section{INTRODUCTION}

The Populus genus is a very rich and variable genus, exhibiting a high variability in terms of morphology, levels of biomass production, and resistance to biotic and abiotic stresses [60]. The subdivision of the genus is still a subject of discussion and many studies have tried to relate variability in productivity as well as in tolerance to environmental changes to variability in leaf characteristics, with variable success depending on the growth conditions [21,60]. This study aims to clarify the relationships between leaf anatomical as well as

\footnotetext{
*Corresponding author: Reinhart.ceulemans@ua.ac.be
} 
morphological characteristics and productivity, on one hand, and taxon, on the other hand.

The genus Populus is a member of the Salicaceae family and is subdivided into six taxonomically distinct sections $[18,21]$. There are approximately 30 species that are widely distributed, mainly in the Northern hemisphere. The sections Aigeiros and Tacamahaca comprise most of the species of economic importance. Species of these sections are sexually compatible and natural interspecific hybridization occurs [71]. The placement of species within a section has traditionally been based on morphological and reproductive characteristics, as well as on interspecific crossability [21,71]. However, classical taxonomic analysis, based on morphological characteristics, has proven to be very difficult because of wide intraspecific heteroblasty, high natural crossability among members of the genus, and the convergent morphology shown by hybrids and their parental species $[16,63]$. Relative indicators of parentage are still needed.

Poplar is extremely well suited to biomass production because of its rapid juvenile growth, high photosynthetic capacity [5], and large woody biomass production in a single growing season $[6,28,29,36]$. The increasing interest in intensive poplar culture requires a better understanding of the mechanisms determining productivity. Interspecific and intersectional hybrids are known to exhibit strong growth vigour as compared with their parents [44]. However, large differences in productivity and in its functional and structural determinants have been observed among poplars, particularly within the Tacamahaca and Aigeiros sections and their hybrids $[10,15,65]$. A productivity determinant can be defined as a characteristic implied in the differences of productivity levels between trees, and thus as a potential indicator of this productivity level. Leaf traits need to present several properties to be considered as relevant productivity determinants: (1) to show a significant degree of variation among the different genotypes, (2) to be strongly linked to biomass production, and (3) the link with biomass production has to be stable under varying environmental conditions [43]. From a practical point of view, breeders are interested in early and easily measurable indicators of the future performance of the genotypes.

The relevance of various traits, both at the whole plant and at the leaf levels, as determinants of productivity has already been studied in poplar. At crown level, tree architecture and canopy density are also intimately related to stand productivity. Crown architecture determines leaf display, leaf distribution and canopy density, and therefore influences light interception [27]. It has been demonstrated that the main factor giving rise to the high leaf area index of poplars is sylleptic branching $[55,68]$. Thus, branch traits, such as syllepsis versus prolepsis, have been incorporated in the formulation of the poplar breeding ideotype for biomass production, i.e., idealized phenotype $[15,19]$. Large differences exist in crown architecture among poplar species. For instance, $P$. trichocarpa is known to differ significantly from $P$. deltoides in many morphological, anatomical and physiological traits, especially in branching habits $[31,68]$. Syllepsis is known to be common in $P$. trichocarpa and $P$. nigra, but rare in $P$. deltoides $[44,60]$. At the leaf level, functional and structural components associated with high growth rates and productivity include total as well as individual leaf area, internal leaf morphology, stomatal morphology and behaviour, leaf growth physiology, and functional traits such as photosynthetic performance $[5,13,32,53]$. Two of the main factors limiting productivity during the growing season are the time necessary to reach maximal leaf area and the ability to maintain leaf area [39]. According to Ridge et al. [57] significant genotypic variation exists in the three physiological components that control total leaf area of poplar trees: individual leaf growth, rate of leaf production and duration of leaf expansion. Genotypic differences in all three variables have been observed among and between the hybrids between $P$. deltoides and P. nigra as well as between $P$. deltoides and P. trichocarpa $[13,14,42]$. Changes in the anatomy and physiology of plant organs in response to environmental stimuli are well documented in poplar [22,35,40,45,46]. Light affects leaf characteristics such as leaf morphology $[1,7,48,49,51]$, leaf anatomy, and stomatal conductance and density $[52,62]$. The relevance of the use of leaf traits as determinants of biomass production as well as for taxonomic applications is therefore strongly dependent on the growth conditions of the concerned plant material. For instance, it has been shown that leaf area and leaf number increment are robust indicators of productivity under various environmental conditions, while the links between productivity and specific leaf area vary according to growth irradiance and temperature as well as with the age of the plants [41,43-45]. Thus, the finding of stable determinants remains an open question, and only a few studies have examined the relevance of leaf anatomy and stomatal characteristics for this purpose.

In this context, the objectives of the present paper are (1) to estimate the relevance of a wide number of leaf anatomical characteristics as indicators of taxon of the genotypes, and as determinants of biomass production, and (2) to test the robustness of these relationships for two canopy positions.

\section{MATERIALS AND METHODS}

\subsection{Experimental plantation}

\subsubsection{Lay-out}

In April 1996, 17 poplar (Populus) genotypes were planted on an experimental field site of 0.56 ha in an industrial zone at Boom, province of Antwerp (Belgium, 51 ${ }^{\circ} 05^{\prime} \mathrm{N}, 4^{\circ} 22^{\prime} \mathrm{E}$; $5 \mathrm{~m}$ above sea level). The plantation was situated on an old waste disposal site, covered with a $2 \mathrm{~m}$ thick layer of sand, clay and mixed rubble.

Hardwood cuttings (25-cm long) were planted in a double-row design with alternating inter-row distances of $0.75 \mathrm{~m}$ and $1.5 \mathrm{~m}$, and a spacing of $0.9 \mathrm{~m}$ within rows accommodating an overall density of 10000 trees per ha. The plantation design was adapted to the layout of a suite of mirror English plantations [4,37]. A randomised block design with 17 genotypes $\times 3$ replications was adopted according to the protocol prescribed by the UK Forestry Commission [4]. Each mono genotypic plot ( $n=100$ trees) had ten rows wide by ten columns deep, and the interior $6 \times 6$ trees constituted the measurement plot with a double buffer row encircling the plot [70]. The plantation was irrigated shortly after planting and mechanical weed control was applied to promote optimal establishment. 


\subsubsection{Plant material and management regime}

The cuttings that did not establish in 1996 were replaced in the spring of 1997 with new hardwood cuttings. At the end of the establishment year in December 1996, as well as after the first rotation cycle of four years in January 2001, all shoots were cut back to a height of $5 \mathrm{~cm}$ to create a multi-shoot coppice system. No fertilisation or irrigation was applied after the establishment of the experiment. Limited chemical weed control techniques were applied during the course of the plantation when the mechanical weeding became insufficient. On three occasions (in June 1996, June 1997 and May 2001) herbicides (a mixture of glyphosate at $3.2 \mathrm{~kg} \mathrm{ha}^{-1}$ and oxadiazon at $9.0 \mathrm{~kg} \mathrm{ha}^{-1}$ ) were applied using a spraying device with a hood-covered nozzle to reduce the impact on trees. Further details on the plantation including site management, history and plant materials can be found in [17] and [36].

All 17 poplar genotypes had been selected for superior biomass production and disease resistance and were representative of the commercially available hybrids, species and taxa in Europe. A subset of 12 genotypes was selected for the current study. The primary selection criterion was the requirement to achieve a range of biomass production and leaf sizes and to avoid large gaps in the canopy caused by non-uniform shoot mortality. The studied genotypes belong to different taxa and hybrid groups: Balsam Spire (BS) belongs to P. trichocarpa T.\&G. $\times$ P. balsamifera $\mathrm{L}$. $(\mathrm{T} \times \mathrm{B}$, section Tacamahaca); Beaupré (BE), Hazendans (HD), Raspalje (RA) and Unal (UN) belong to $P$. trichocarpa $\times P$. deltoides Marsh. $(\mathrm{T} \times \mathrm{D}$, sections Tacamahaca $\times$ Aigeiros); Columbia River (CR), Fritzi Pauley (FP) and Trichobel (TR) belong to P. trichocarpa (T, section Tacamahaca); Gaver (GA), Gibecq (GI) and Primo (PR) belong to P. deltoides $\times$ P. nigra L. $(\mathrm{D} \times \mathrm{N}$, section Aigeiros); and Wolterson (WO) belongs to P. nigra (N, section Aigeiros) [53]. At the time of sampling, all stools essentially consisted of unbranched vertical shoots allowing us to study the influence of differences in leaf characteristics on stand-level light impact independently of branching.

\subsection{Leaf anatomy and stomata}

During the third growing season of the second coppice rotation (August 2003) two recently mature leaves per replication plot were collected from 12 randomly selected homogenous shoots per genotype and per plot from two different canopy positions, i.e. the upper (top $2 \mathrm{~m}$ of each shoot) and the lower ones $(1.5 \mathrm{~m}$ above the soil level). Only mature leaves were sampled from both the upper and the lower canopy positions. Excised leaves were put in plastic bags with moistened filter paper (to protect leaves from drying out) and brought to the laboratory for stomatal impressions and anatomical cross-sections.

Replicate impressions of abaxial and adaxial leaf epidermis were taken at the point of maximum leaf width near the central vein of the leaf, using colourless nail polish and adhesive cellophane tape. All impressions were fixed on glass slides and examined under a light microscope (Orthoplan Leitz, Germany, with JVC camera connected to JVC TV, Germany, and projected on a screen) at a magnification of $\times 100$. At least 20 microscopic fields from the abaxial and 10 from the adaxial leaf surface were randomly selected per leaf. Stomata were counted and stomatal density (adaxial stomatal density, SDd, and abaxial stomatal density, SDb) was calculated as the number of stomata per unit leaf area $\left(\mathrm{mm}^{-2}\right)$ (Tab. I). Imaging of every stomatal impression from both abaxial and adaxial leaf surfaces was done
Table I. Abbreviations, units and descriptions of the traits analysed in the present study.

\begin{tabular}{|c|c|c|c|}
\hline & Trait & Description & Unit \\
\hline Biomass & Prod & Biomass production & $\mathrm{Mg} \mathrm{ha}^{-1} \mathrm{y}^{-1}$ \\
\hline \multirow{3}{*}{ Leaf morphology } & SLA & Specific leaf area & $\mathrm{cm}^{2} \mathrm{~g}^{-1}$ \\
\hline & $\mathrm{N}_{\mathrm{M}}$ & Leaf nitrogen concentration & $\operatorname{mg~g}^{-1}$ \\
\hline & LA & Leaf area & $\mathrm{cm}^{2}$ \\
\hline \multirow{4}{*}{ Leaf anatomy } & EdT & Adaxial epidermis thickness & $\mu \mathrm{m}$ \\
\hline & $\mathrm{PpT}$ & Palisade parenchyma thickness & $\mu \mathrm{m}$ \\
\hline & $\mathrm{SpT}$ & Spongy parenchyma thickness & $\mu \mathrm{m}$ \\
\hline & EbT & Abaxial epidermis thickness & $\mu \mathrm{m}$ \\
\hline \multirow{5}{*}{ Stomata } & TLT & Total leaf thickness & $\mu \mathrm{m}$ \\
\hline & SDd & Adaxial stomatal density & $\mathrm{mm}^{-2}$ \\
\hline & $\mathrm{SDb}$ & Abaxial stomatal density & $\mathrm{mm}^{-2}$ \\
\hline & SLd & Adaxial stomatal length & $\mu \mathrm{m}$ \\
\hline & $\mathrm{SLb}$ & Abaxial stomatal length & $\mu \mathrm{m}$ \\
\hline
\end{tabular}

with a Zeiss Axioskop (Germany) microscope equipped for a Nikon DXM1200 (Japan) digital camera at a magnification of $\times 200$. Stomatal length (adaxial stomatal length, SLd, and abaxial stomatal length, $\mathrm{SLb})$ was defined as the length of the stomatal complex. Stomatal length was measured by using the ScionImage program [2].

Anatomical determinations were made on $60 \mu \mathrm{m}$ thick transverse cross-sections at the point of maximum leaf width. The sections were made by a hand microtome (R. Jung, Heidelberg, Germany). Crosssections were put in $50 \%$ of PBS $\left(25 \mathrm{~mm} \mathrm{Na}_{2} \mathrm{HPO}_{4}\right.$ and $0.15 \mathrm{M} \mathrm{NaCl}$, $\mathrm{pH} 7.4$ ) and $50 \%$ glycerol on glass slides to clear the sections under the light microscope. Imaging of every leaf cross-section was done with a Zeiss Axioskop (Germany) microscope equipped for a Nikon DXM1200 (Japan) digital camera at a magnification of $\times 200$ and $\times 400$. Measurements were made with the ScionImage program. Internal anatomical organization of the leaves was characterized by the thicknesses of adaxial epidermis (EdT), palisade parenchyma (PpT), spongy parenchyma (SpT), abaxial epidermis (EbT), total leaf thickness (TLT), and the ratio palisade/spongy parenchyma (Tab. I).

\subsection{Morphological leaf characteristics}

In August 2003, 10 homogenous shoots per replicate plot were randomly selected for each genotype and harvested at $5 \mathrm{~cm}$ above soil level. Every shoot was divided into one meter sections. All leaves of each $1 \mathrm{~m}$ section were removed and brought to the laboratory for various measurements. Individual leaf area (LA) was measured for all leaves using a laser area meter (CID Inc. type CI-203, USA). Leaf dry mass (DM) of 30 randomly chosen leaves per $1 \mathrm{~m}$ section were determined after drying at $75{ }^{\circ} \mathrm{C}$ in a forced air oven until constant dry mass was reached. Specific leaf area (SLA) was calculated as LA/DM.

After drying, 30 leaves were ground to a fine powder and analyzed for leaf nitrogen $(\mathrm{N})$ concentration using the Dynamic Flush Combustion Method with a Soil Auto-analyser (Carlo-Erba, Instr. type NC 2100, Italy). Each sample was analyzed twice; the detection limit of the instrument was $0.01 \%$. Leaf $\mathrm{N}$ concentrations were calculated on a dry mass basis and expressed as $\mathrm{mg}^{-1}$ of dry mass. One or 
Table II. Regression coefficients $a$ and $b$ of the equations between shoot diameter $(\mathrm{mm})$ and shoot dry mass $(\mathrm{g})$ for the 12 poplar genotypes at the end of a three-year rotation in a short rotation coppice culture. The established equation is: Dry mass $=a$ Diameter $^{b}$. All regression coefficients $\left(r^{2}\right)$ were significant at $P \leqslant 0.001$. The range of shoot diameters used and the estimated biomass production $( \pm \mathrm{SE})$ are indicated for each genotype.

\begin{tabular}{lcccccc}
\hline & \multicolumn{3}{c}{ Regression parameters } & \multicolumn{2}{c}{ Input } & \multicolumn{2}{c}{ Output } \\
\hline Genotype & $a$ & $b$ & $r^{2}$ & $\begin{array}{c}\text { Range of shoot } \\
\text { diameters }(\mathrm{mm})\end{array}$ & $\begin{array}{c}\text { Biomass } \\
\left(\mathrm{t} \mathrm{ha}^{-1} \mathrm{y}^{-1}\right)\end{array}$ & $\pm \mathrm{SE}$ \\
\hline Beaupré & 0.11 & 2.47 & 0.97 & $8.9-66.5$ & 2.79 & \pm 0.33 \\
Hazendans & 0.53 & 1.97 & 0.97 & $3.9-52.5$ & 3.53 & \pm 0.54 \\
Raspalje & 0.06 & 3.05 & 0.73 & $1.5-57.3$ & 4.57 & \pm 0.62 \\
Unal & 0.11 & 2.54 & 0.93 & $3.3-56.6$ & 3.89 & \pm 0.32 \\
\hline Columbia River & 0.21 & 2.3 & 0.93 & $2.0-72.8$ & 6.21 & \pm 0.47 \\
Fritzi Pauley & 0.24 & 2.31 & 0.96 & $4.7-68.6$ & 8.24 & \pm 0.42 \\
Trichobel & 0.11 & 2.53 & 0.94 & $2.9-71.9$ & 8.23 & \pm 1.50 \\
Balsam Spire & 0.09 & 2.60 & 0.87 & $1.1-66.2$ & 7.52 & \pm 0.40 \\
\hline Gaver & 0.17 & 2.43 & 0.93 & $3.8-65.6$ & 7.49 & \pm 0.35 \\
Gibecq & 0.48 & 2.12 & 0.95 & $6.1-63.8$ & 3.25 & \pm 0.77 \\
Primo & 0.12 & 2.48 & 0.96 & $5.8-64.9$ & 5.97 & \pm 0.83 \\
\hline Wolterson & 0.25 & 2.27 & 0.90 & $2.4-67.0$ & 9.66 & \pm 0.10 \\
\hline
\end{tabular}

two genotypes of each taxon (i.e. BS, CR, PR, UN, and WO) were used for the establishment of the canopy profile (i.e. six canopy positions, every one meter high) of LA, SLA and N. For the seven other genotypes, LA, SLA and N were determined, like for anatomical and stomatal traits, for two canopy positions only, i.e. top $2 \mathrm{~m}$ of each shoot and $1.5 \mathrm{~m}$ above soil level.

\subsection{Biomass production}

At the end of the third growing season of the second rotation, diameter of all shoots was determined at $22 \mathrm{~cm}$ above soil level by using a digital calliper (Mitutoyo, type CD-15DC, UK) [54]. Thirty shoots per genotype (ten shoots per plot) were then selected using the technique of the quantils of the total, so that the sampled shoots represented the total basal area and its variation within a replicate plot $[8,9]$ and harvested at $5 \mathrm{~cm}$ above soil level. Dry mass of the whole shoots was determined after drying in a forced air oven at $105^{\circ} \mathrm{C}$ until constant mass was reached. Least-square regression equations between shoot diameter and shoot dry mass were used to determine aboveground biomass production per genotype: $\mathrm{M}=a \mathrm{D}^{b}$, with $a$ and $b$ as regression coefficients, $\mathrm{D}$ as shoot diameter, and $\mathrm{M}$ as shoot dry mass [36]. Different equations were obtained and used for the 12 genotypes (see Tab. II for the $a$ and $b$ regression coefficients and the range of shoot diameters per genotype). Productivity was obtained by dividing the biomass production by the number of growing seasons in this rotation: Productivity (Prod, $\mathrm{Mg} \mathrm{ha}^{-1} \mathrm{y}^{-1}$ ) $=$ Biomass production/3 years.

\subsection{Statistical analyses}

Data were analysed using the Statistical Package SPSS, version 11.0, 2001 (SPSS, Chicago, IL). The Shapiro-Wilk test was used to check the normal distribution of the traits. Means were calculated with their standard error $( \pm S E)$. Data were evaluated by analysis of variance according to the two following models:

- for productivity, $Y_{j}^{\prime}=\mu+G_{j}+\varepsilon_{j}$,

- and for leaf anatomical, stomatal and morphological traits, $Y_{j k}^{\prime}=\mu+G_{j}+P_{k}+G \times P+\varepsilon_{j k}$,

where $Y^{\prime}{ }_{j}$ and $Y^{\prime}{ }_{j k}$ are individual values adjusted for plot effects, when plot effect was significant at $P \leqslant 0.05\left(Y^{\prime}=Y-B_{i}\right.$, where $B_{i}$ is the estimated effect of plot $i$ ), $\mu$ is the general mean, $G$ is the genotypic effect (random), $P$ is the canopy position effect (random) and $G \times P$ is the genotype by canopy position interaction effect (random). To quantify the relative importance of each effect, variance components $\sigma_{G}^{2}, \sigma_{P}^{2}, \sigma_{G \times P}^{2}$, and $\sigma_{\varepsilon}^{2}$ were calculated by equating observed mean squares to expected mean squares and solving the resulting equations [30]. Inter-genotype comparisons were followed by a Scheffé test. All differences were considered significant at $P \leqslant 0.05$.

Relationships between parameters were tested using Pearson's correlation coefficient. The effect of canopy height on SLA, LA and $\mathrm{N}_{\mathrm{M}}$ was tested using Spearman's rank coefficients. The study of the inter-genotype variability and of the relationships between leaf characteristics was performed by using Principal Components Analysis (PCA). The basic variables were standardized and orthogonal factors $\left(=\mathrm{PC}_{1}\right.$ and $\mathrm{PC}_{2}$ axis) were successively built as linear combinations of these variables to maximize the part of the variability explained by these factors. The PCA was performed with genotypic means of variables at the upper and lower canopy positions, separately. Variables were first represented on the plane defined by the two main factors of the PCA; their coordinates were their linear correlation coefficient (Pearson's coefficient) with these factors. Traits measured for the lower canopy position were also projected, as supplementary variables, in the main plane previously defined for the upper canopy position. In this way, linear correlations were calculated between the lower canopy variables and $\mathrm{PC}_{1}$ and $\mathrm{PC}_{2}$ factors. The variables TLT, $\mathrm{PpT} / \mathrm{SpT}$ ratio and $\mathrm{SDd} / \mathrm{SDb}$ ratio were not included because they were derived from the other traits.

\section{RESULTS}

\subsection{Productivity}

The mean productivity differed significantly among genotypes. Mean annual biomass production ranged from 2.8 ton $\mathrm{ha}^{-1} \mathrm{y}^{-1}$ for BE (T×D taxon) to 9.7 ton $\mathrm{ha}^{-1} \mathrm{y}^{-1}$ for WO (N taxon) (Tab. II). All genotypes could be subdivided into two distinct categories: high biomass producers belonging to the $\mathrm{T}, \mathrm{T} \times \mathrm{B}$, and $\mathrm{N}$ taxa (BS, FP, TR, CR, and WO) and low biomass producers belonging to the $\mathrm{T} \times \mathrm{D}$ and $\mathrm{D} \times \mathrm{N}$ taxa $(\mathrm{HD}$, RA, UN, BE, GA, GI, and PR).

\subsection{Leaf traits}

\subsubsection{Anatomical leaf characteristics}

Cross-section leaf characteristics differed significantly among genotypes belonging to the different taxa and between 
Table III. General means and standard error $( \pm$ SE) of anatomical leaf characteristics at the upper and the lower canopy positions for the 12 poplar genotypes. See Table I for abbreviations of variable names. The parentage abbreviations are: $\mathrm{T}=P$. trichocarpa, $\mathrm{D}=P$. deltoides, $\mathrm{N}$ $=P$. nigra, and $\mathrm{B}=P$. balsamifera

\begin{tabular}{|c|c|c|c|c|c|c|c|c|c|c|c|c|}
\hline \multirow{2}{*}{ Genotype } & \multirow{2}{*}{ Section } & \multirow{2}{*}{ Taxon } & \multicolumn{2}{|c|}{$\operatorname{EdT}(\mu \mathrm{m})$} & \multicolumn{2}{|c|}{$\mathrm{PpT}(\mu \mathrm{m})$} & \multicolumn{2}{|c|}{$\mathrm{SpT}(\mu \mathrm{m})$} & \multicolumn{2}{|c|}{$\operatorname{EbT}(\mu \mathrm{m})$} & \multicolumn{2}{|c|}{ Ratio PpT/SpT } \\
\hline & & & Upper & Lower & Upper & Lower & Upper & Lower & Upper & Lower & Upper & Lower \\
\hline \multirow[t]{2}{*}{ Beaupré } & & & 17.6 & 17.0 & 111.1 & 75.3 & 155.4 & 133.8 & 15.1 & 13.0 & 0.71 & 0.56 \\
\hline & Tacamahaca $\times$ & & 0.8 & \pm 0.6 & \pm 4.2 & \pm 3.6 & \pm 2.8 & \pm 1.6 & \pm 0.5 & \pm 0.3 & \pm 0.04 & \pm 0.02 \\
\hline \multirow[t]{2}{*}{ Hazendans } & Aigeiros & & 15.7 & 13.4 & 121.3 & 64.9 & 183.8 & 116.9 & 14.1 & 11.6 & 0.66 & 0.56 \\
\hline & & $\mathrm{T} \times \mathrm{D}$ & \pm 0.2 & \pm 0.6 & \pm 3.4 & \pm 3.9 & \pm 1.4 & \pm 3.1 & \pm 0.6 & \pm 0.3 & \pm 0.02 & \pm 0.03 \\
\hline \multirow[t]{2}{*}{ Raspalje } & & & 15.1 & 12.4 & 97.0 & 65.9 & 151.3 & 113.9 & 14.6 & 11.6 & 0.64 & 0.58 \\
\hline & & & \pm 0.4 & \pm 0.6 & \pm 4.4 & \pm 0.9 & \pm 3.6 & \pm 4.7 & \pm 0.5 & \pm 0.4 & \pm 0.03 & \pm 0.03 \\
\hline \multirow[t]{2}{*}{ Unal } & & & 17.7 & 13.1 & 107.5 & 70.3 & 152.6 & 111.8 & 14.5 & 11.4 & 0.70 & 0.63 \\
\hline & & & \pm 0.9 & \pm 0.3 & \pm 2.0 & \pm 2.6 & \pm 6.5 & \pm 6.0 & \pm 0.2 & \pm 0.5 & \pm 0.02 & \pm 0.03 \\
\hline \multirow[t]{2}{*}{ Columbia River } & & & 18.0 & 13.5 & 118.5 & 68.0 & 166.3 & 92.9 & 14.4 & 12.3 & 0.71 & 0.73 \\
\hline & & & \pm 0.7 & \pm 0.2 & \pm 7.2 & \pm 2.7 & \pm 3.5 & \pm 3.9 & \pm 0.8 & \pm 0.1 & \pm 0.05 & \pm 0.02 \\
\hline \multirow[t]{2}{*}{ Fritzi Pauley } & Tacamahaca & $\mathrm{T}$ & 16.4 & 12.8 & 120.5 & 64.9 & 217.9 & 107.6 & 14.4 & 11.6 & 0.55 & 0.60 \\
\hline & & & \pm 0.9 & \pm 0.3 & \pm 4.7 & \pm 2.2 & \pm 6.7 & \pm 1.3 & \pm 0.4 & \pm 0.7 & \pm 0.03 & \pm 0.03 \\
\hline \multirow[t]{2}{*}{ Trichobel } & & & 16.0 & 12.6 & 103.7 & 59.5 & 184.4 & 103.1 & 13.3 & 10.2 & 0.56 & 0.58 \\
\hline & & & \pm 0.7 & \pm 0.6 & \pm 3.9 & \pm 1.5 & \pm 5.1 & \pm 2.4 & \pm 0.5 & \pm 0.4 & \pm 0.03 & \pm 0.02 \\
\hline \multirow[t]{2}{*}{ Balsam Spire } & & $\mathrm{T} \times \mathrm{D}$ & 18.1 & 12.8 & 91.2 & 66.8 & 140.0 & 96.0 & 13.1 & 11.1 & 0.65 & 0.70 \\
\hline & & & \pm 0.9 & \pm 0.3 & \pm 1.8 & \pm 2.2 & \pm 2.3 & \pm 6.3 & \pm 0.6 & \pm 0.3 & \pm 0.02 & \pm 0.04 \\
\hline \multirow[t]{2}{*}{ Gaver } & & & 14.0 & 12.4 & 143.0 & 61.3 & 95.3 & 82.0 & 12.4 & 10.9 & 1.50 & 0.75 \\
\hline & & & \pm 0.3 & \pm 0.6 & \pm 3.9 & \pm 0.9 & \pm 2.2 & \pm 5.2 & \pm 0.2 & \pm 0.4 & \pm 0.04 & \pm 0.04 \\
\hline \multirow[t]{2}{*}{ Gibeq } & Aigeiros & $\mathrm{D} \times \mathrm{N}$ & 14.7 & 13.1 & 148.3 & 79.6 & 99.1 & 109.4 & 12.9 & 11.2 & 1.50 & 0.73 \\
\hline & & & \pm 0.2 & \pm 0.3 & \pm 2.2 & \pm 2.3 & \pm 3.3 & \pm 4.4 & \pm 0.3 & \pm 0.5 & \pm 0.05 & \pm 0.04 \\
\hline \multirow[t]{2}{*}{ Primo } & & & 14.9 & 12.0 & 136.2 & 64.9 & 91.4 & 81.4 & 12.5 & 11.3 & 1.49 & 0.80 \\
\hline & & & \pm 0.4 & \pm 0.4 & \pm 3.4 & \pm 5.1 & \pm 2.5 & \pm 7.1 & \pm 0.3 & \pm 0.6 & \pm 0.01 & \pm 0.02 \\
\hline \multirow[t]{2}{*}{ Wolterson } & & $\mathrm{N}$ & 18.4 & 13.5 & 94.1 & 65.9 & 137.8 & 79.2 & 15.1 & 10.6 & 0.68 & 0.83 \\
\hline & & & \pm 0.5 & \pm 0.7 & \pm 0.8 & \pm 1.7 & \pm 1.8 & \pm 6.7 & \pm 0.4 & \pm 0.4 & \pm 0.01 & \pm 0.07 \\
\hline
\end{tabular}

canopy positions (Tabs. III and IV). The genotype by canopy position interaction was significant for most anatomical traits, except for the thickness of the abaxial epidermis (EbT).

The leaves of the genotypes of the Tacamahaca $(\mathrm{T}, \mathrm{T} \times \mathrm{B})$ and Tacamahaca $\times$ Aigeiros $(\mathrm{T} \times \mathrm{D})$ sections were thicker than the leaves of the genotypes of the Aigeiros $(\mathrm{N}, \mathrm{D} \times \mathrm{N})$ section, irrespective of canopy position. In most of the genotypes, the thickness of the spongy parenchyma layer (SpT) was higher than the thickness of the palisade parenchyma layer $(\mathrm{PpT})$, irrespective of canopy position (except for genotypes of the $\mathrm{D} \times \mathrm{N}$ taxon at the upper canopy position). Genotypes of the section Tacamahaca $(\mathrm{T}$ and $\mathrm{T} \times \mathrm{B})$ had the highest SpT as compared with other genotypes at the upper canopy position, especially with genotypes of the $\mathrm{T}$ taxon. Genotypes of the Aigeiros section had the lowest SpT because they exhibited a double palisade layer at the upper canopy position only (Fig. 1). Adaxial epidermis thickness (EdT) was higher than the abaxial one (EbT) for all genotypes, irrespective of canopy level. Overall, leaves in the upper canopy position were thicker for all measured anatomical layers than the lower canopy leaves.

At the upper canopy position, the $\mathrm{PpT} / \mathrm{SpT}$ ratio was higher for genotypes of $\mathrm{D} \times \mathrm{N}$ than for the other genotypes. At the lower canopy position, the highest $\mathrm{PpT} / \mathrm{SpT}$ ratio was observed for the $\mathrm{N}$ and $\mathrm{D} \times \mathrm{N}$ taxa. Genotypes with thin leaves had a significantly higher $\mathrm{PpT} / \mathrm{SpT}$ ratio than genotypes with thicker leaves. The PpT/SpT ratio correlated significantly and negatively with total leaf thickness (TLT) at the upper $(r=$ $-0.76 ; P \leqslant 0.001)$ and the lower $(r=-0.65 ; P \leqslant 0.001)$ canopy positions, while TLT showed significant and positive correlations with SpT at both the upper $(r=0.70 ; P \leqslant 0.001)$ and the lower $(r=0.68 ; P \leqslant 0.001)$ canopy positions.

\subsubsection{Stomatal traits}

Means and standard errors of stomatal traits can be found in [2]. Genotypic and canopy position effects as well as the interaction between both were highly significant for most stomatal traits, except for the interaction effect of the adaxial stomatal length (Tab. IV). All traits showed a very high genotypic effect, representing $34 \%$ to $84 \%$ of the phenotypic variance.

\subsubsection{Morphological leaf traits}

Leaf area (LA), specific leaf area (SLA) and leaf N concentration $\left(\mathrm{N}_{\mathrm{M}}\right)$ differed significantly among genotypes belonging to the different taxa, and varied as a function of shoot height (Fig. II and Tabs IV and V). LA increased gradually with height, i.e. smaller leaves were at the bottom of the shoot, while the largest leaves were located at the last two meters of 
Table IV. Relative importance of genotypic $\left(\sigma_{G}^{2}\right)$, canopy position $\left(\sigma_{P}^{2}\right)$, genotype by canopy position $\left(\sigma_{G \times P}^{2}\right)$, and residual $\left(\sigma_{\varepsilon}^{2}\right)$ effects in the phenotypic variation $\left(\sigma_{P h}^{2}\right)$ of leaf anatomy (EdT, PpT, SpT, and EbT), stomatal traits (SDd, SDb, SLd, and SLb), leaf morphological traits (LA, SLA, and $\mathrm{N}_{M}$ ), and biomass production (Prod). See Table I for definitions of trait abbreviations. Level of significance of each effect is indicated by asterisks: $\mathrm{ns}=$ non significant; $*=P \leqslant 0.05 ; * *$ $=P \leqslant 0.01 ;$ and $* * *=P \leqslant 0.001$.

\begin{tabular}{lcccc}
\hline \multirow{2}{*}{ Trait } & \multicolumn{4}{c}{ Variance components $(\%)$} \\
\cline { 2 - 5 } Biomass & $\alpha_{C}^{2} / \alpha_{P h}^{2}$ & $\alpha_{P}^{2} / \alpha_{P h}^{2}$ & $\alpha_{G \times P}^{2} / \alpha_{P h}^{2}$ & $\alpha_{\epsilon}^{2} / \alpha_{P h}^{2}$ \\
Prod & $61.6 * *$ & - & - & 38.4 \\
Leaf structure & & & \\
LA & $1.1 * * *$ & $68.1 * * *$ & $16.8 * * *$ & 14.0 \\
SLA & $0.0 *$ & $76.7 * * *$ & $9.9 * *$ & 13.4 \\
$\mathrm{~N}_{\mathrm{M}}$ & $21.0 * * *$ & $70.2 * * *$ & $3.7 * *$ & 5.0 \\
Leaf anatomy & & & & \\
EdT & $10.6 * * *$ & $60.3 * * *$ & $9.9 * * *$ & 19.2 \\
PpT & $1.7 * * *$ & $82.8 * * *$ & $11.3 * * *$ & 4.2 \\
SpT & $14.7 * * *$ & $50.0 * * *$ & $30.0 * * *$ & 5.3 \\
EbT & $7.2 * * *$ & $64.1 * * *$ & $3.5 \mathrm{~ns}$ & 25.3 \\
Ratio & $21.9 * * *$ & $14.1 * * *$ & $58.6 * * *$ & 5.4 \\
Stomata & & & & \\
SLd & $72.9 * * *$ & $13.0 * * *$ & $0.87 \mathrm{~ns}$ & 13.2 \\
SLb & $83.6 * * *$ & $5.9 * * *$ & $3.5 * * *$ & 6.9 \\
SDd & $67.7 * * *$ & $16.3 * * *$ & $14.5 * * *$ & 1.5 \\
SDb & $33.8 * * *$ & $48.0 * * *$ & $16.5 * * *$ & 1.7 \\
\hline
\end{tabular}

the shoot (Fig. 2C). SLA increased from the top to the bottom (Fig. 2A). On the contrary, $\mathrm{N}_{\mathrm{M}}$ decreased from the top to the bottom (Fig. 2B). LA, SLA and $\mathrm{N}_{\mathrm{M}}$ were significantly linked to canopy height $(P \leqslant 0.001)$, except for $\mathrm{N}_{\mathrm{M}}$ of $\mathrm{UN}$. Overall, the variation among genotypes of the same taxon was smaller than between genotypes of different taxa.

\subsection{Relationships between traits}

The main plane of the PCA $\left(\mathrm{PC}_{1} \times \mathrm{PC}_{2}\right)$ established for the upper canopy position explained $63.4 \%$ of the inter-genotype variability and $\mathrm{PC}_{1}$ alone explained $40.0 \%$. The $\mathrm{PC}_{3}$ axis did not significantly differentiate the traits (data not shown). At the lower canopy position, the main plane of the PCA ( $\mathrm{PC}_{1}{ }_{1} \times$ $\mathrm{PC}_{2}{ }_{2}$ ) explained $60.1 \%$ of the inter-genotype variability with $\mathrm{F}_{1}$ alone explaining $40.6 \%$. To avoid redundancy, only the $\mathrm{PC}_{1} \times \mathrm{PC}_{2}$ plane established for the upper canopy position is presented, with traits measured at the lower canopy position projected as supplementary variables (Fig. 3A). At both canopy positions, three groups of variables were defined from the $\mathrm{PC}_{1} \times \mathrm{PC}_{2}$ plane:

(1) the first group included $\mathrm{N}_{\mathrm{M}}, \mathrm{SDb}$, and Prod;

(2) the second group included EbT, EdT, LA, SLb, and SpT;

(3) and the third one included SLA, PpT and SDd.

At the lower canopy position only, trait SLb was not associated with any of the groups. The $\mathrm{PC}_{1}$ axis of the PCA was defined by the opposition between the second and the third groups. SDd, SLA, and PpT (sum of adaxial and abaxial PpT for genotypes of the $\mathrm{D} \times \mathrm{N}$ taxon) scaled negatively with $\mathrm{EbT}$, EdT, LA, SpT, and SLb. The $\mathrm{PC}_{2}$ axis was mainly defined by the traits belonging to the first group. The first group was independent from both other groups. The groups composed of the supplementary variables (measured at the lower canopy position) overlapped with groups of traits measured at the upper canopy position in most cases, except concerning variables of the second group, associated with $\mathrm{PC}_{1}$ at the upper canopy position and with $\mathrm{PC}_{2}$ at the lower one.

At both canopy positions, and within each group, most of the variables were positively correlated (Tab VI). The projection of the genotypes in the main planes of the PCA showed a clear grouping among genotypes in the $\mathrm{PC}_{1} \times \mathrm{PC}_{2}$ plane. Genotypes were grouped according to four trends (Fig. 3B):

- cluster A included BS, CR, TR, and FP (T and T $\times$ B taxa, section Tacamahaca);

- cluster B included BE, HD, RA, and UN (T $\times \mathrm{D}$ taxon, Tacamahaca $\times$ Aigeiros);

- cluster C included GA, GI, and PR (D×N taxon, section Aigeiros);

- and cluster D is only composed of WO ( $\mathrm{N}$ taxon, section Aigeiros).

The genotypes in cluster A displayed high Prod, $\mathrm{N}_{\mathrm{M}}$, and $\mathrm{SDb}$ with thick (high TLT) and hypostomatous leaves, while the genotype of cluster D had high Prod, $\mathrm{N}_{\mathrm{M}}$ and SDb with relatively thin (low TLT) and amphistomatous leaves. Genotypes of cluster B displayed thick leaves with low Prod and $\mathrm{N}_{\mathrm{M}}$, while genotypes of cluster $\mathrm{C}$ had thin leaves with double palisade layers and displayed low Prod (Fig. 3B, Tab. V).

\section{DISCUSSION}

In the present study, the hybrids resulting from the crosses between P. deltoides, P. trichocarpa and P. nigra were the least productive genotypes as compared with pure species. Many studies have shown the high growth potential of Interamerican (P. trichocarpa $\times$ P. deltoides) as well as Euramerican (P. nigra $\times P$. deltoides) hybrids during the first years of short rotation cultures $[38,43-45,55]$. Our results showed that this hybrid superiority was no longer observed in a second-rotation plantation. Hybrid vigor decreases with the aging of the plant material, and hybrid genotypes seem to have a reduced biomass production in plantations with a high number of rotations.

\subsection{Relationships between leaf traits and productivity}

In this study, a large variability was observed for leaf traits among the poplar genotypes, in agreement with previous studies on various species and hybrids $[43,45,55]$. Biomass production was positively scaled with adaxial stomatal density and nitrogen concentration of both canopy positions. Likewise, previous studies have shown a positive correlation between stomatal density and fast growth in different plant 


\section{Upper canopy level}

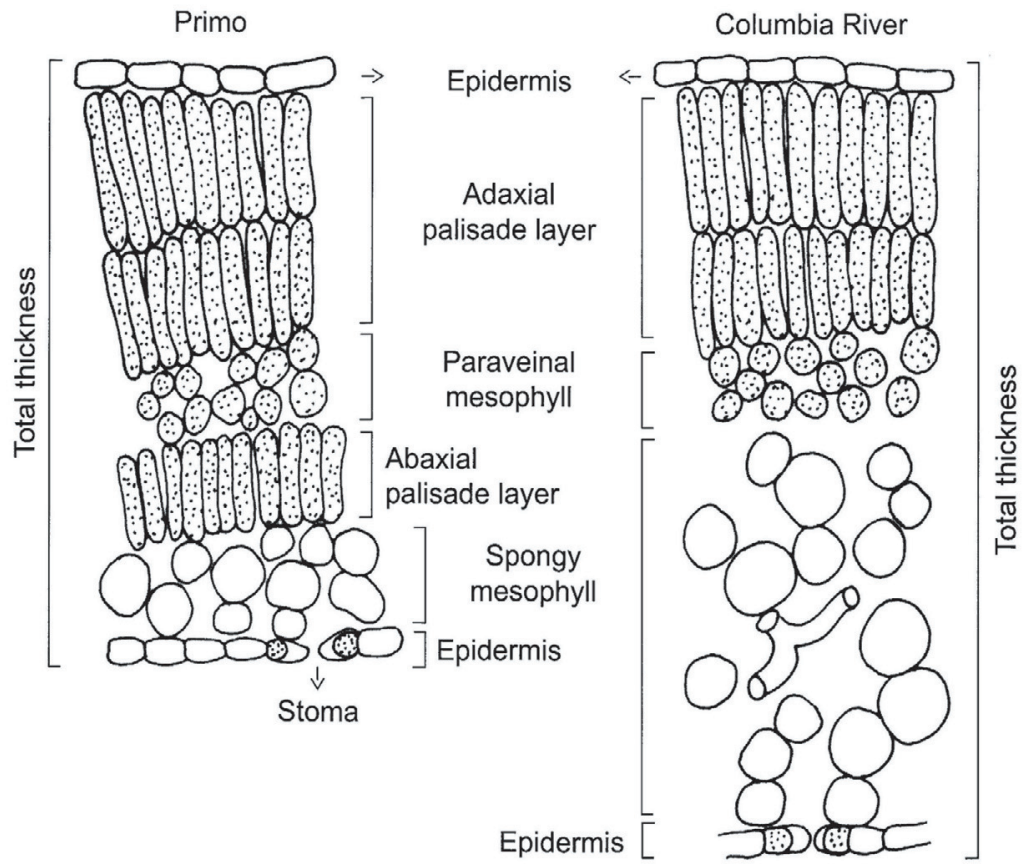

Figure 1. Schematic representation of leaf cross-sections for Primo (P. deltoides $\times$ P. nigra) and Columbia River $(P$. trichocarpa) at the upper canopy level.
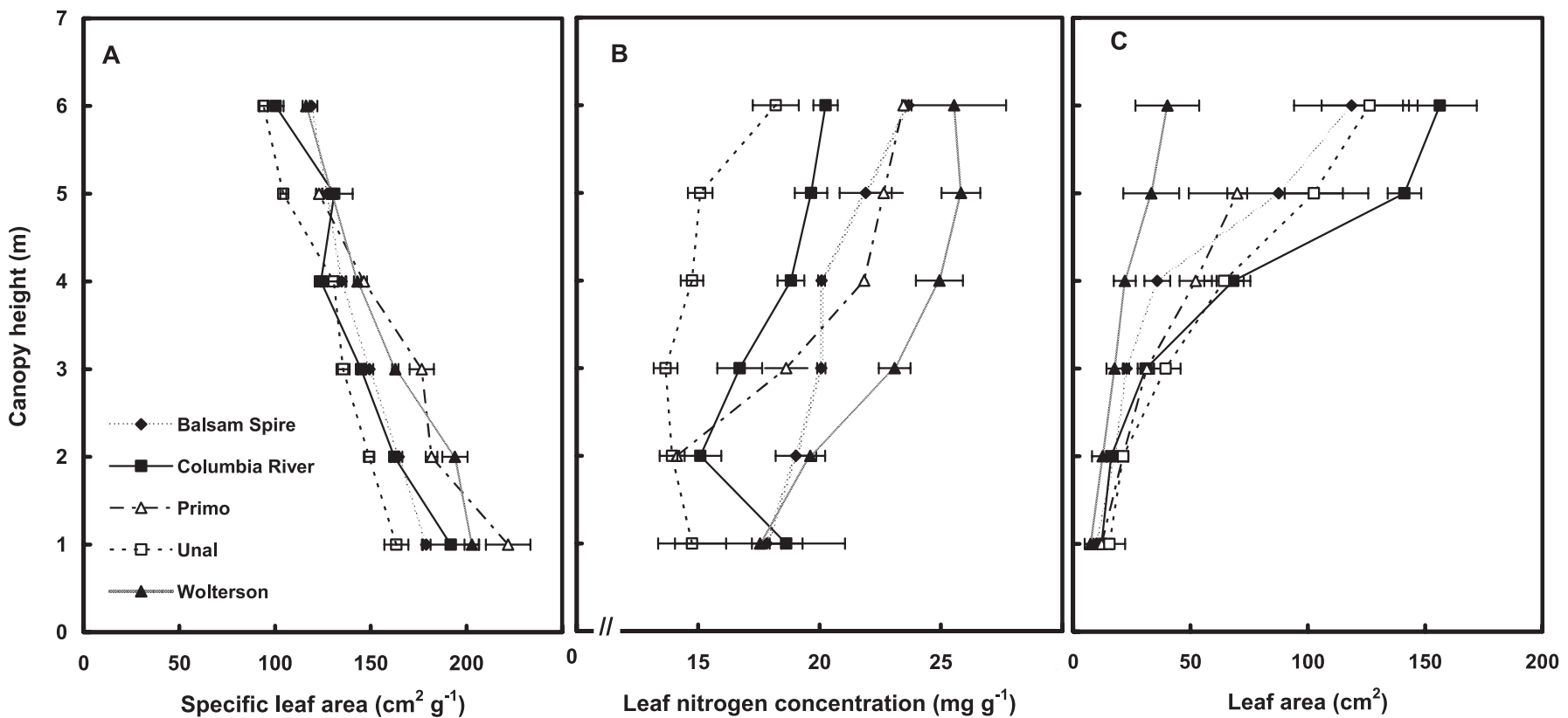

Figure 2. Canopy profiles of specific leaf area (A), leaf nitrogen concentration (B), and leaf area (C) of five poplar genotypes: Balsam Spire $(P$. trichocarpa $\times$ P. balsamifera); Columbia River $(P$. trichocarpa); Primo $(P$. deltoides $\times P$. nigra $)$; Unal $(P$. trichocarpa $\times$. deltoides $)$, and Wolterson $(P$. nigra). Mean values $( \pm \mathrm{SE})$ of three replicates per genotype. 
Table V. Relative values of leaf characteristics of the different sections and taxa. $(+)=$ high value, $(-)=$ low value, and $(+/-)=$ intermediate value. See Table I for definition of abbreviations. Trait SLb belongs to group 3 at the upper canopy position and is independent of all groups at the lower canopy position. The parentage abbreviations are: $\mathrm{T}=P$. trichocarpa, $\mathrm{D}=P$. deltoides, $\mathrm{N}=P$. nigra, and $\mathrm{B}=$ P. balsamifera.

\begin{tabular}{|c|c|c|c|c|c|c|}
\hline & Cluster A & \multicolumn{2}{|c|}{ Cluster B } & \multicolumn{2}{|c|}{ Cluster C } & Cluster D \\
\hline Section & Tacamahaca & \multicolumn{2}{|c|}{$\begin{array}{c}\text { Tacamahaca } \times \\
\text { Aigeiros }\end{array}$} & \multicolumn{3}{|c|}{ Aigeiros } \\
\hline Taxon & $\mathrm{T}, \mathrm{T} \times \mathrm{B}$ & \multicolumn{2}{|c|}{$T \times D$} & \multicolumn{2}{|c|}{$\mathrm{D} \times \mathrm{N}$} & $\mathrm{N}$ \\
\hline $\begin{array}{l}\text { Canopy } \\
\text { Group } 1\end{array}$ & Upper Lower & Upper & Lower & Upper & Lower & Upper Lower \\
\hline Prod & + & 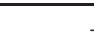 & - & - & + & + \\
\hline $\mathrm{N}_{\mathrm{M}}$ & + & 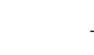 & - & - & $+/-$ & + \\
\hline $\mathrm{SDb}$ & + & $+/-$ & - & - & $+/-$ & + \\
\hline Group 2 & & & & & & \\
\hline EdT & + & $+/-$ & - & & - & - \\
\hline $\mathrm{EbT}$ & + & $+/-$ & - & & - & - \\
\hline SpT & + & . & + & & - & - \\
\hline LA & + & 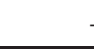 & + & & - & - \\
\hline Group 3 & & & & & & \\
\hline $\mathrm{PpT}$ & - & $+1-$ & - & & + & $+/-$ \\
\hline SDd & - & - & - & & + & $+/-$ \\
\hline SLA & - & - & & & + & $+/-$ \\
\hline $\mathrm{SLb}$ & + & . & + & & - & - \\
\hline
\end{tabular}

species $[34,66]$. For genotypes of $P$. deltoides and $P . \times e u$ ramericana, Orlovic et al. [52] found a positive correlation between adaxial stomatal density and biomass production, and the author proposed to use this correlation for the selection of nursery stock for biomass production. The positive correlation between abaxial stomatal density and above-ground biomass production, valid for both canopy positions and associated with a very high relative genotypic variance for stomatal traits, confirmed the potential of stomatal characteristics as early indicators of genotypic productivity. Stomata are responsible for both leaf $\mathrm{CO}_{2}$ input, needed for photosynthesis, and $\mathrm{H}_{2} \mathrm{O}$ release, responsible for the sap flow within the plant, and consequently have a primordial role in plant growth physiology. Our results underlined the fact that the number of stomata per unit leaf area, rather than the size of individual stomata, affects biomass accumulation in a larger proportion. However, the stomatal length is not necessarily related to the degree to which stomata are opened and additional measurements, notably of stomatal conductance, would be needed to make final conclusions in this regard. Moreover, Ceulemans et al. [12] found no significant correlation between stomatal density (either adaxial or abaxial) and yield for genotypes of $\mathrm{N}, \mathrm{T} \times \mathrm{D}$, and $\mathrm{D} \times \mathrm{N}$ taxa. On the contrary, these authors found a positive and significant correlation between stomatal length and yield. The validity and robustness of the relationships observed between biomass production and leaf anatomical or stomatal traits therefore need to be further investigated for other taxa, growth conditions and plantation age.

\subsection{Relationships between leaf traits and taxonomy}

The genus Populus has six taxonomical sections [21]. There is still a question of sectional affiliation with regard to the relationships between the sections Aigeiros and Tacamahaca, and the status of $P$. nigra [21]. In this study, genotypic variations in leaf characteristics were related to the taxon, and they were grouped depending on the section taxonomy.

Genotypes belonging to the Tacamahaca section showed thick and large leaves with low SLA, stomata with high density and length at the abaxial leaf surface, and high leaf nitrogen concentration (Tab. V). Tacamahaca leaves are very thick and this large thickness is related to the thick, loosely arranged spongy parenchyma layer $[15,24,57,65,67]$. To confirm this result, total leaf thickness correlated positively with spongy parenchyma thickness and negatively with the ratio between palisade and spongy parenchyma thicknesses. Thus, genotypes with thick leaves had a thicker spongy parenchyma layer, and a small ratio between palisade and spongy parenchyma thicknesses. Moreover, the abaxial leaf side of $P$. trichocarpa genotypes is generally white due to a thick and loosely structured spongy mesophyll, whereas it is green in $P$. deltoides because of bilateral palisade parenchyma layers [15, 24, 57, 65, 70]. Leaves of $P$. trichocarpa are known to have a small number of large stomata and a low ratio of adaxial/abaxial stomatal densities [15, 22, 24]. Moreover, P. trichocarpa genotypes (section Tacamahaca) have hypostomatous leaves in contrast to the amphistomatous leaves of $P$. deltoides and $P$. nigra species (section Aigeiros) [2,11].

Genotypes belonging to the Aigeiros section showed thin and small leaves with high SLA, stomata with low density and small stomatal length at the abaxial leaf surface, and low leaf nitrogen concentration (Tab. V). Actually, leaves of $P$. deltoides generally show a large number of small stomata and a high ratio of adaxial/abaxial densities [15,24]. Within the Aigeiros section, the P. nigra genotype (WO) was an exception, showing thin leaves with high abaxial stomatal density and high leaf nitrogen concentration (Tab. V). P. nigra is known to produce leaves with large stomata and with a ratio of adaxial/abaxial densities intermediate between those of $P$. trichocarpa and P. deltoides [58, 64]. Rajora and Dancik [56] have proposed a new section, Nigrae for P. nigra, which is separated from other species in the Aigeiros section. Based on genetic molecular markers, $P$. nigra was clearly separated from its consectional $P$. deltoides, and should be classified separately according to Cervera et al. [10]. Although our results are consistent with the conclusions of the previously cited studies, the use of only one P. nigra genotype in the present study does not allow us to conclude about this aspect, nor to confirm or contradict previous findings.

Hybrids resulting from crosses between the Tacamahaca $\times$ Aigeiros sections showed intermediate characteristics, but with more similarities with the Tacamahaca than with the Aigeiros section (Tab. V). Van Volkenburgh and Taylor [65] reported 
Table VI. Linear correlations (Pearson's coefficients) between leaf anatomy (EdT, PpT, SpT, and EbT), stomatal traits (SDd, SDb, SLd, and $\mathrm{SLb}$ ), leaf morphological traits (LA, SLA, and $\mathrm{N}_{M}$ ), and biomass production (Prod) at the upper (normal font) and the lower (italic font) canopy positions. Level of significance is indicated by asterisks: $\mathrm{ns}=$ non significant; $*=P \leqslant 0.05 ; * *=P \leqslant 0.01$; and $* * *=P \leqslant 0.001$. See Table $\mathrm{I}$ for definitions of trait abbreviations.

\begin{tabular}{|c|c|c|c|c|c|c|c|c|c|c|c|c|}
\hline & \multicolumn{4}{|c|}{ Stomata } & \multicolumn{4}{|c|}{ Leaf anatomy } & \multicolumn{3}{|c|}{ Leaf structure } & \multirow{2}{*}{$\frac{\text { Biomass }}{\text { Prod }}$} \\
\hline & SDd & $\mathrm{SDb}$ & $\mathrm{SLb}$ & SLd & EdT & $\mathrm{SpT}$ & PpT & $\mathrm{EbT}$ & $\mathrm{N}_{\mathrm{M}}$ & SLA & $\mathrm{LA}$ & \\
\hline \multicolumn{13}{|c|}{ Biomass } \\
\hline Prod & ns & $0.63 *$ & ns & ns & ns & ns & ns & ns & $0.69 *$ & ns & ns & \\
\hline \multicolumn{13}{|c|}{ Leaf structure } \\
\hline LA & $-0.73 * *$ & ns & ns & ns & ns & ns & ns & ns & ns & $-0.71 *$ & & ns \\
\hline SLA & $0.59 *$ & ns & $-0.58 *$ & ns & ns & $-0.75 *$ & ns & ns & ns & & ns & ns \\
\hline $\mathrm{N}_{\mathrm{M}}$ & ns & $0.68 *$ & $-0.71 *$ & ns & ns & ns & ns & ns & & ns & ns & $0.53 *$ \\
\hline \multicolumn{13}{|c|}{ Leaf anatomy } \\
\hline $\mathrm{EbT}$ & ns & ns & ns & ns & $0.64 *$ & $-0.63 *$ & $0.59 *$ & & ns & ns & ns & ns \\
\hline $\mathrm{PpT}$ & ns & ns & $-0.58 *$ & ns & ns & ns & & ns & ns & ns & ns & $-0.66 *$ \\
\hline $\mathrm{SpT}$ & $-0.59 *$ & ns & $0.78 * *$ & $0.91 * *$ & ns & & ns & $0.58 *$ & ns & ns & ns & $-0.73 *$ \\
\hline $\mathrm{EdT}$ & ns & ns & ns & ns & & ns & $0.61 *$ & ns & ns & ns & ns & ns \\
\hline \multicolumn{13}{|c|}{ Stomata } \\
\hline SLd & ns & ns & $0.97 * * *$ & & ns & ns & ns & ns & ns & ns & ns & ns \\
\hline SLb & $-0.77 * *$ & ns & & $0.97 * * *$ & ns & ns & ns & ns & ns & ns & ns & ns \\
\hline $\mathrm{SDb}$ & ns & & ns & ns & ns & ns & ns & ns & $0.6 *$ & ns & ns & $0.75 * *$ \\
\hline SDd & & ns & $-0.77 * *$ & ns & ns & ns & ns & ns & ns & ns & ns & ns \\
\hline
\end{tabular}
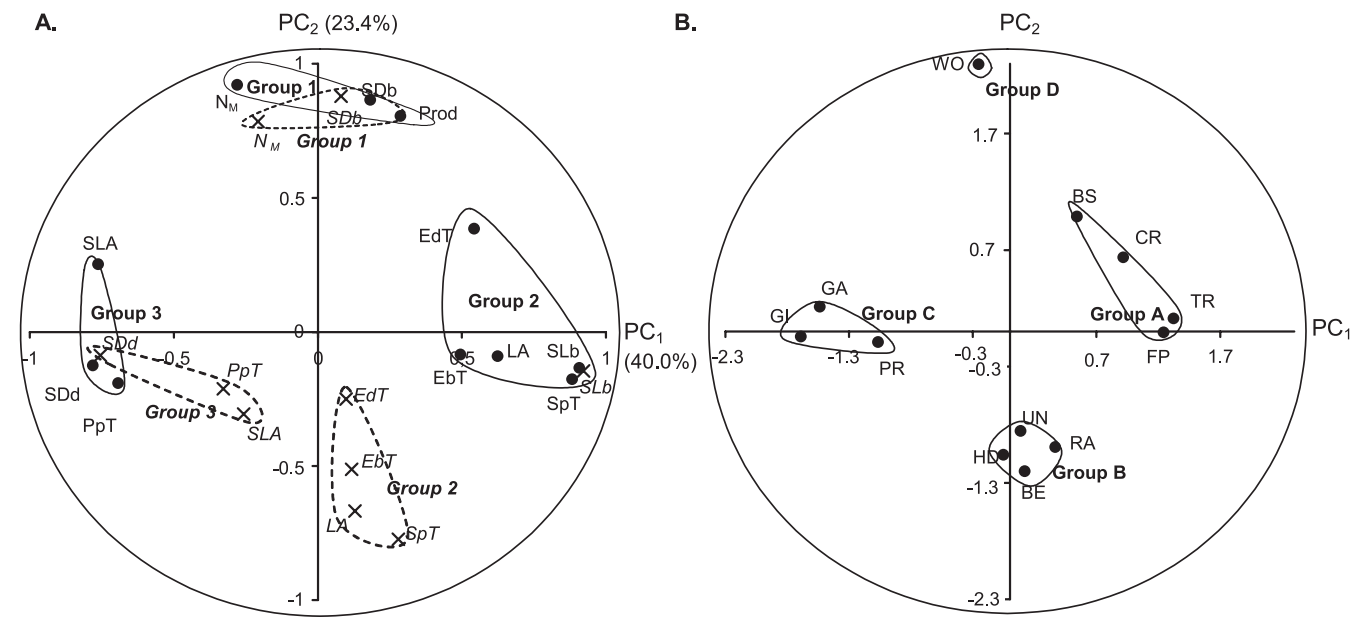

Figure 3. Distribution of the 11 traits $(\mathrm{A})$ and projection of the 12 poplar genotypes (B) in the factorial plane $\mathrm{PC}_{1} \times \mathrm{PC}_{2}$ of the $\mathrm{PCA}_{\mathrm{A}}$ established for the upper canopy position ( $\bullet$ / normal font / continuous lines). Axis $\mathrm{PC}_{1}$ and $\mathrm{PC}_{2}$ are linear combinations of the 11 traits and were constructed to maximize the part of the data variability that they explained. Traits measured at the lower canopy position were projected, as supplementary variables, in the main plane $\mathrm{PC}_{1} \times \mathrm{PC}_{2}(\times /$ italic font / dashed lines). See Table I and Materials and Methods section for abbreviations of variable and genotype names, respectively.

that leaf growth characteristics of P. trichocarpa and P. deltoides and of their hybrids differed. Leaf area in P. trichocarpa is primarily obtained from cell expansion, whereas in $P$. deltoides leaf area is primarily obtained from cell division. In general, hybrids between these two species mainly inherit their stomatal characteristics from $P$. trichocarpa and present an intermediate ratio of adaxial/abaxial densities [2,24]. The hybrids between $P$. deltoides and $P$. nigra also show intermediate values of stomatal density, length and ratio of adaxial/abaxial densities as compared with the parental species $[2,24]$.

\subsection{Relationships between leaf morphology and height in the canopy}

In the present study, leaf area, specific leaf area, and nitrogen concentration varied with canopy depths. Casella and Ceulemans in 2002 [7] have shown for the same plantation that irradiance could vary from $22 \mathrm{~mol}$ of PAR per $\mathrm{m}^{2}$ and per day at $7 \mathrm{~m}$ above ground level to $3 \mathrm{~mol}$ of PAR per $\mathrm{m}^{2}$ and per day at $1 \mathrm{~m}$ above ground level. Previous studies have already shown the strong impact of irradiance on leaf 
morphology: upper canopy leaves are generally longer and larger than lower canopy leaves $[1,7,28,51]$. Larger top canopy leaves generally take advantage of the higher irradiance by exposing a larger surface to sun. In tobacco, leaves tended to be small under low irradiance; leaf size increased with irradiance until a certain level was reached [61].

SLA had high values in the lower canopy and decreased gradually from the bottom to the top of the canopy. SLA is known to be very sensitive to changes in irradiance, and scales negatively with light $[1,3,26,48-51]$. In contrast, the study of Marron et al. [40] reported that SLA was mostly dependent on leaf developmental stage (mature vs. expanding leaves). In the present study, the observed variations were the result of the combined effects of irradiance and leaf aging, leaves at the base of the stems being the oldest ones and age decreasing from the bottom to the top of the stem. The variations in SLA are usually related to leaf thickness and/or leaf density $[49,59]$. An increase in leaf thickness is primarily due to an additional photosynthetic component mesophyll layer, as well as to larger cells in each mesophyll layer [33,49]. On the other hand, an increase in leaf density is due to thicker cell walls and to smaller and more tightly packed cells $[25,49]$. In our study, SLA was almost independent of the thickness of the anatomical layer, showing a higher dependence of SLA on leaf density than on leaf thickness.

SLA correlated negatively with the nitrogen concentration in this study, in agreement with other studies $[49,50]$. Consequently, the increase in nitrogen concentration from the lower to the upper canopy with decreasing SLA suggests that palisade and spongy layer thicknesses increased in line with the profile of nitrogen concentration. Yano and Terashima [69] reported that the light environment of mature leaves altered the thickness of leaves along with the anatomy of the palisade layer. It has already been shown that nitrogen varies from the upper canopy to the lower canopy in different woody plants [23] including poplar [7]. The profiles of SLA and nitrogen followed a pattern parallel to the light gradients, thus acclimating to light availability within the canopy. Photosynthetic capacities are known to increase with nitrogen for a wide range of ecotypes, species and genera [20,23,47,59].

\section{CONCLUSIONS AND PERSPECTIVES}

Our study has shown that: (1) leaf nitrogen concentration, abaxial stomatal density, and thickness of the spongy and palisade parenchyma are associated with biomass production and could be used as indicators of growth potential dependent upon where in the canopy the association is made, (2) variation in leaf anatomy and morphology was often explainable in terms of the varietal taxon, and (3) hybrids between Tacamahaca and Aigeiros sections exhibited leaf characteristics intermediate between the two sections, and showed a relatively low biomass production as compared with pure species. Results are indicative of trends that need to be confirmed in future studies, including a wider random sample of genotypes belonging to other taxa (notably $P$. deltoides genotypes), con- trasting growth conditions, and short-rotation plantations of various ages.

Acknowledgements: This study is being supported by a research contract of the Province of Antwerp (Belgium). The project has been carried out in close cooperation with Eta-com B., supplying the grounds and part of the infrastructure, and with the logistic support of the city council of Boom (Belgium). All plant materials were kindly provided by the Institute for Forestry and Game Management (Geraardsbergen, Belgium) and by the Forest Research, Forestry Commission (UK). We gratefully acknowledge Z. Hleibie and J. Willems for their help with data collection, A. Muys for help with Fig. 1, as well as Prof. J.P. Verbelen and S. Foubert for use of the microscope infrastructure, and two anonymous reviewers for their constructive comments. The first author is supported by a fellowship from the Syrian University (Al Baath).

\section{REFERENCES}

[1] Al Afas N., Pellis A., Niinemets Ü., Ceulemans R., Growth and production of a short rotation coppice culture of poplar. II. Clonal and year-to-year differences in leaf and petiole characteristics and stand leaf area index, Biomass Bioenerg. 28 (2005) 536-547.

[2] Al Afas N., Marron N., Ceulemans R., Clonal variation in stomatal characteristics related to biomass production under short rotation coppice culture, Environ. Exp. Bot. 58 (2006) 279-286.

[3] Anten N.P.R., Hirose T., Biomass allocation and light partition among dominant and subordinate individuals in Xanthium canadense stands, Ann. Bot. 82 (1998) 665-673.

[4] Armstrong A., United Kingdom network of experiments on site/yield relationships for short rotation coppice. Forestry Commission Research Information, Forestry Commission, Edinburgh, UK, 1997, Note 294.

[5] Barigah T.S., Saugier B., Mousseau M., Guittet J., Ceulemans R., Photosynthesis, leaf area and productivity of 5 poplar clones during their establishment year, Ann. For. Sci. 51(1994) 613-625.

[6] Bunn S.M., Rae A.M., Herbert C.S., Taylor G., Leaf-level productivity traits in Populus grown in short rotation coppice for biomass energy, Forestry 77 (2004) 307-323.

[7] Casella E., Ceulemans R., Spatial distribution of leaf morphology and physiological characteristics in relation to local radiation regime within the canopies of 3-year-old Populus clones in coppice culture, Tree Physiol. 22 (2002) 1277-1288.

[8] Cermák J., Kucera J, Scaling up transpiration data between trees, stands and watersheds, Silva Carelica 15 (1990) 101-120.

[9] Cermák J., Riguzzi F., Ceulemans R, Scaling up from the individual tree to the stand level in Scots pine. I. Needle distribution, overall crown and root geometry, Ann. For. Sci. 55 (1998) 63-88.

[10] Cervera M.T., Storme V., Soto A., Ivens B., Van Montagu M., Rajora O.P., Boerjan W., Intraspecific and interspecific genetic and phylogenetic relationships in the genus Populus based on AFLP markers, Theor. Appl. Genet. 111 (2005) 1440-1456.

[11] Ceulemans R., Impens I., Lemeur R., Moermans R., Samsuddin Z., Water movement in the soil-poplar-atmosphere system. I. Comparative study of stomatal morphology and anatomy, and the influence of stomatal density and dimensions on the leaf diffusion characteristics in different poplar clones, Oecol. Plant. 13 (1978) $1-12$.

[12] Ceulemans R., Impens I., Steenackers V., Stomatal and anatomical leaf characteristics of 10 Populus clones, Can. J. Bot. 62 (1984) 513-518.

[13] Ceulemans R., Impens I., Imler R, Stomatal conductance and stomatal behavior in Populus clones and hybrids, Can. J. Bot. 66 (1988) 1404-1414. 
[14] Ceulemans R., Stettler R.F., Hinckley T.M., Isebrands I., Heilman P.E, Crown architecture of Populus clones as determined by branch orientation and branch characteristics, Tree Physiol. 7 (1990) 157167.

[15] Ceulemans R., Genetic variation in functional and structural productivity determinants in poplar. Thesis Publishers, Amsterdam, The Netherlands, 1990, p. 100.

[16] Cronk Q.C.B., Plant eco-devo: the potential of poplar as a model organism, New Phytol. 166 (2005) 39-48.

[17] Deraedt W., Ceulemans R., Clonal variability in biomass production and conversion efficiency of poplar during the establishment year of a short rotation coppice plantation, Biomass Bioenerg. 15 (1998) 391-398.

[18] Dickmann D.I., Stuart K.W., The Culture of Poplar in Eastern North America. Michigan State University, East Lansing, Michigan, USA, 1983.

[19] Dickmann D.I., Gold M.A., Flore J.A, The ideotype concept and the genetic improvement of trees crops, Plant Breed. Rev. 12 (1994) 163-193.

[20] Eamus D., Prichard H., A cost-benefit analysis of leaves of four Australian savanna species, Tree Physiol. 18 (1998) 537-545.

[21] Eckenwalder J.E., Systematic and evolution of Populus, in: Stettler R.F. Bradshaw H.D. Jr. Heilman P.E. Hinckley T.M. (Eds), Biology of Populus and its Implications for Management and Conservation. Ottawa: NRC Research Press, National Research Council of Canada, 1996, pp. 7-32.

[22] Ferris R., Long L., Bunn S.M., Robinson K.M., Bradshaw H.D. Jr., Rae A., Taylor G., Leaf stomatal and epidermal cell development: identification of putative quantitative trait loci in relation to elevated carbon dioxide concentration in poplar, Tree Physiol. 22 (2002) 633-640.

[23] Field C., Merino J., Mooney H.A., Compromises between water-use efficiency and nitrogen-use efficiency in five species of California evergreens, Oecologia 60 (1983) 384-389.

[24] Figliola A.L., Studies in the physiology, morphology and anatomy of Populus trichocarpa, Populus deltoides and their hybrids, M. Sc. thesis, University of Washington, Seattle, USA, 1986, p. 127.

[25] Garnier E., Laurent G., Leaf anatomy, specific mass and water content in congeneric annual and perennial grass species, New Phytol. 128 (1994) 725-736.

[26] Gielen B., Liberloo M., Bogaert J., Calfapietra C., De Angelis P., Miglietta F., Scarascia-Mugnozza G., Ceulemans R., Three years of free-air $\mathrm{CO}_{2}$ enrichment (POPFACE) only slightly affect profiles of light and leaf characteristics in closed canopies of Populus, Glob. Change Biol. 9 (2003) 1-16.

[27] Hallé F., Oldeman R.A., Tomlinson P.B., Tropical trees and forests: an architectural analysis. Springer-Verlag, Berlin, Germany, 1978, p. 441.

[28] Hansen E.A., Poplar woody biomass yields: a look to the future, Biomass Bioenerg. 1 (1991) 1-7.

[29] Heilman P.E., Ekuan G., Fogle D., Above- and below-ground biomass and fine roots of 4-year-old hybrids of Populus trichocarpa $\times$ Populus deltoides and parental species in short rotation culture, Can. J. For. Res. 24 (1994) 1186-1192.

[30] Henderson C.R., Estimation of variance and co-variance components, Biometrics 9 (1953) 226-252.

[31] Hinckley T.M., Ceulemans R., Dunlap J.M., Figliola A., Heilman P.E., Isebrands J.G., Scarascia-Mugnozza G., Schulte P.J., Smit B., Stettler R.F., Van Volkenburgh E., Wiard B.M., Physiological, morphological and anatomical components of hybrids vigour in Populus, in: Kreeb K.H., Richter H., Hinckley T.M. (Eds.) Structural and functional responses to environmental stresses, SPB Academic Publishing, The Hague, The Netherlands, 1989, p. 199217.
[32] Isebrands J.G., Nelson N.D., Crown architecture of short-rotation, intensively cultured Populus. II. Branch morphology and distribution of leaves within the crown of Populus 'Tristis' as related to biomass production, Can. J. For. Res. 12 (1982) 853-864.

[33] Korner C., Neumayer M., Pelaez-Riedl S., Smeete-Scheel S., Functional morphology of mountain plants, Flora 182 (1989) 353383.

[34] Kundu S.K., Tigerstedt P.M.A., Variation in net photosynthesis, stomatal characteristics, leaf area and whole plant photomass production among ten provenances of name (Azadirachta indica), Tree Physiol. 19 (1999) 47-52.

[35] Lambs L., Loubiat M., Girel J., Tissier J., Peltier J.P., Marigo G., Survival and acclimatation of Populus nigra to drier conditions after damming of an alpine river, southeast France, Ann. For. Sci. 63 (2006) 377-385.

[36] Laureysens I., Pellis A., Willems J., Ceulemans R., Growth and production of a short rotation coppice culture of poplar. III. Second rotation results, Biomass Bioenerg. 29 (2005) 10-21.

[37] Ledin S., Willebrand E., Handbook on how to grow short rotation forests. Swedish University of Agricultural Sciences, Sweden, 1995.

[38] Li B., Wu R., Genetic cause of heterosis in juvenile aspen: a quantitative comparison across intra- and inter-specific hybrids. Theor, Appl. Genet. 93 (1996) 380-391.

[39] Loomis R.S., Williams W.A., Maximum crop productivity: an estimate, Crop Sci. 3 (1963) 67-72.

[40] Marron N., Delay D., Petit J.-M., Dreyer E., Kahlem G., Delmotte F.M., Brignolas F., Physiological traits of two Populus $\times$ euramericana clones, Luisa Avanzo and Dorskamp, during a water stress and re-watering cycle, Tree Physiol. 22 (2002) 849-858.

[41] Marron N., Dreyer E., Boudouresque E., Delay D., Petit J-M., Delmotte F.M., Brignolas F., Impact of successive drought and rewatering cycles on growth and specific leaf area of two Populus $\times$ canadensis (Moench) clones, 'Dorskamp' and 'Luisa_Avanzo', Tree Physiol. 23 (2003) 1225-1235.

[42] Marron N., Villar M., Dreyer E., Delay D., Boudouresque E., Petit J-M., Delmotte F.M., Guehl J.M., Brignolas F., Diversity of leaf traits related to productivity in 31 Populus deltoides $\times$ Populus nigra clones, Tree Physiol. 25 (2005) 425-435.

[43] Marron N., Ceulemans R., Genetic variation of leaf traits related to productivity in a Populus deltoides $\times$ P. nigra family, Can. J. For. Res. 36 (2006) 390-400.

[44] Marron N., Bastien C., Sabatti M., Taylor G., Ceulemans R., Plasticity of growth and sylleptic branchiness in two poplar families grown at three sites across Europe, Tree Physiol. 26 (2006) 935-946.

[45] Monclus R., Dreyer E., Delmotte F.M., Villar M., Delay D., Boudouresque E., Petit J-M., Marron N., Bréchet C., Brignolas F., Productivity, leaf traits and carbon isotope discrimination in 29 Populus deltoides $\times$ P. nigra clones, New Phytol. 167 (2005) 53-62.

[46] Monclus R., Dreyer E., Villar M., Delmotte F.M., Delay D., Petit J-M., Barbaroux C., Le Thiec D., Bréchet C., Brignolas F., Impact of drought on productivity and water use efficiency in 29 genotypes of Populus deltoides $\times$ Populus nigra, New Phytol. 169 (2006) 757777.

[47] Mooney H.A., Farrar P.J., Slayter R.O., Photosynthetic capacity and carbon allocation patterns in diverse growth forms of Eucalyptus, Oecologia 36 (1978) 103-111.

[48] Niinemets Ü., Role of foliar nitrogen in light harvesting and shade tolerance of four temperate deciduous woody species, Funct. Ecol. 11 (1997) 518-531.

[49] Niinemets Ü., Kull O., Tenhunen J.D., Variability in leaf morphology and chemical composition as a function of canopy light environment in coexisting deciduous trees, Int. J. Plant Sci. 60 (1999) $837-848$ 
[50] Niinemets Ü., Climatic controls of leaf dry mass per area, density and thickness in trees and shrubs at the global scale, Ecology 82 (2001) 453-469.

[51] Niinemets Ü., Al Afas N., Cescatti A., Pellis A., Ceulemans R., Petiole length and biomass investment in support modify lightinterception efficiency in dense poplar plantations, Tree Physiol, 24 (2004) 141-154.

[52] Orlović S., Guzina V., Krstic B., Merkulov L., Genetic variability in anatomical, physiological and growth characteristics of hybrid poplar (Populus $\times$ euramericana Dode (Guinier)) and eastern cottonwood (Populus deltoides Bartr.) clones, Silvae Genet. 47 (1998) 183-190.

[53] Pellis A., Laureysens I., Ceulemans R., Growth and production of a short rotation coppice culture of poplar.I. Clonal differences in leaf characteristics in relation to biomass production, Biomass Bioenerg. 27 (2004) 9-19.

[54] Pontailler J.Y., Ceulemans R., Guittet J., Mau M., Linear and nonlinear functions of volume index to estimate woody biomass in high density young poplar stands, Ann. For. Sci. 54 (1997) 335-345.

[55] Rae A.M., Robinson K.M., Street N.R., Taylor G., Morphological and physiological traits influencing biomass productivity in shortrotation coppice culture, Can. J. For. Res. 34 (2004) 1488-1498.

[56] Rajora O.P., Dancik B.P., Chloroplast DNA variation in Populus. II. Interspecific restriction fragment polymorphisms and genetic relationships among Populus deltoides, P. nigra, P. maximowiczii, and P. canadensis, Theor. Appl. Genet. 90 (1995) 324-330.

[57] Ridge C.R., Hinckley T.M., Stettler R.F., Van Volkenburgh E., Leaf growth characteristics of fast-growing poplar hybrids Populus trichocarpa $\times$ P. deltoides. Tree Physiol. (1986) 1, 209-216.

[58] Schreuder M.D.J., Van Hove L.W.A., Brewer C.A., Ozone exposure affects leaf wettability and tree water balance, New Phytol. 152 (2001) 443-454.

[59] Sefton C.A., Montagu K.D., Atwell B.J., Conroy J.P., Anatomical variation in juvenile leaves accounts for differences in specific leaf area and $\mathrm{CO}_{2}$ assimilation rates, Aust. J. Bot. 50 (2002) 301-310.

[60] Stettler R.F., Zsuffa L., Wu R., The role of hybridization in the genetic manipulation of Populus, in: Stettler R.F., Bradshaw H.D. Jr., Heilman P.E., Hinckley T.M. (Eds.), Biology of Populus and its implications for management and conservation, Ottawa, NRC Research Press, National Research Council of Canada, 1996, pp. 283-299.
[61] Thomas P., Woodward F.I., Quick W.P., Systemic irradiance signalling in tobacco, New Phytol. 161 (2003) 193-198.

[62] Ticha I., Photosynthetic characteristics during ontogenesis of leaves. 7. Stomata density and sizes, Photosynthetica 16 (1982) $375-471$.

[63] Vanden Broeck A., Villar M., Van Bockstaele E., Van Slycken J., Natural hybridization between cultivated poplars and their wild relatives: evidence and consequences for native poplar populations, Ann. For. Sci. 62 (2005) 601-613.

[64] Vanden Broeck A., Cottrell J., Quataert P., Breyne P., Storme V., Boerjan W., Van Slycken J., Paternity analysis of Populus nigra offspring in a Belgian plantation of native and exotic poplars, Ann. For. Sci. 63 (2006) 783-790.

[65] Van Volkenburgh E., Taylor G., Leaf growth physiology, in: Stettler R.F., Bradshaw H.D. Jr., Heilman P.E., Hinckley T.M. (Eds.), Biology of Populus and its implications for management and conservation, Ottawa, NRC Research Press, National Research Council of Canada, 1996, p. 283-299.

[66] Wang T.L., Tigerstedt P.M.A, Vihera-Aarnio A., Photosynthesis and canopy characteristics in genetically defined families of silver birch (Betula pendula), Tree Physiol. 15 (1995) 665-671.

[67] Wu R., Bradshaw H.D. Jr., Stettler R.F., Molecular genetics of growth and development in Populus (Salicaceae). V. Mapping quantitative trait loci affecting leaf variation, Am. J. Bot. 84 (1997) 143153.

[68] Wu R., Stettler R.F, Quantitative genetics of growth and development in Populus. III. Phenotypic plasticity of crown structure and function, Heredity 81 (1998) 299-310.

[69] Yano S., Terashima I., Separate localization of light signal perception for sun and shade type chloroplast and palisade tissue differentiation in Chenopodium album, Plant Cell Physiol. 42 (2001) 13031310.

[70] Zavitkovski J., Structure and seasonal distribution of litterfall in young plantations of Populus 'Tristis-1', Plant Soil 60 (1981) 409422.

[71] Zsuffa L., A summary review of interspecific breeding in the genus Populus L, in: Proceedings of the Canadian Tree Improvement Association, 28-30 August 1973, Fredericton, NB 14 (1975) 107123. 